COSMOPOLITAN CONCEPTIONS 
This page intentionally left blank 


\section{Cosmopolitan Conceptions IVF Sojourns in Global Dubai}

MARCIA C. INHORN

Duke University Press $\quad$ Durham and London 2015 
(C) 2015 Duke University Press

All rights reserved

Printed in the United States of America on acid-free paper $\infty$

Cover design by Natalie F. Smith; interior design by

Heather Hensley

Typeset in Chaparral Pro by Westchester Publishing Services

Library of Congress Cataloging-in-Publication Data

Inhorn, Marcia Claire, [date]

Cosmopolitan conceptions : IVF sojourns in global Dubai /

Marcia C. Inhorn.

pages $\mathrm{cm}$

Includes bibliographical references and index.

ISBN 978-o-8223-5913-5 (hardcover : alk. paper)

ISBN 978-0-8223-5933-3 (pbk. : alk. paper)

ISBN 978-o-8223-7535-7 (e-book)

1. Fertilization in vitro, Human-United Arab Emirates-Dubai.

2. Medical tourism-United Arab Emirates-Dubai. I. Title.

RG135.I5834 2015

362.1981'780599095357-dc23 2015009494

Cover art: Burj Dubai (Burj Khalifa). Dubai, United Arab Emirates.

(C) philipus / Alamy. 
IN HONOR OF

Lowell, Roger, and Kris,

three caring physicians,

and

IN MEMORY OF

Frederick L. Dunn,

physician-anthropologist and mentor 
This page intentionally left blank 